\title{
Defective oxytocin function: a clue to understanding the cause of autism?
}

\author{
Fiorella Gurrieri and Giovanni Neri*
}

\author{
Address: Institute of Medical Genetics, Catholic University School of Medicine, Rome, Italy \\ Email: Fiorella Gurrieri - fgurrieri@rm.unicatt.it; Giovanni Neri* - gneri@rm.unicatt.it \\ * Corresponding author
}

Published: 22 October 2009

BMC Medicine 2009, 7:63 doi:10.1/86/174|-7015-7-63
Received: 21 September 2009

Accepted: 22 October 2009

This article is available from: http://www.biomedcentral.com/I74I-70I5/7/63

(c) 2009 Gurrieri and Neri; licensee BioMed Central Ltd.

This is an Open Access article distributed under the terms of the Creative Commons Attribution License (http://creativecommons.org/licenses/by/2.0), which permits unrestricted use, distribution, and reproduction in any medium, provided the original work is properly cited.

\begin{abstract}
The autism spectrum disorders are a group of conditions with neurobehavioral impairment affecting approximately $0.6 \%$ of children. The clinical presentation is complex and the etiology is largely unknown, although a major role of genetic factors is widely accepted. A number of genetic studies led to the identification of genes and/or copy number variants whose alterations are associated with autism, but no specific factor has been found so far to be responsible for a substantial proportion of cases. Epigenetic modifications may also play a role, as demonstrated by the occurrence of autism in genetic conditions caused by mutations in imprinted genes or regions.

The article by Gregory et al. published this month in BMC Medicine, reports on genomic and epigenetic alterations of OXTR, the gene encoding the receptor for oxytocin. The involvement of this gene was suggested by its deletion in an autistic patient. The subsequent analysis of a group of unrelated autistic subjects did not show an OXTR deletion, but rather hypermethylation of the gene promoter, with a reduced mRNA expression.

These findings address two major points of the current debate on the etiology and pathogenesis of autism: the role of oxytocin, known to be involved in modeling human behavior, and the possible involvement of epigenetic mechanisms. The nature of this epigenetic dysregulation is unknown but, if proved to be true, might explain the failure to identify sequence alterations in a host of candidate genes. Practical implications of these findings may be forthcoming, however not before extension and validation on a larger scale have confirmed their value.

See the associated research paper by Gregory et al: http://www.biomedcentral.com/I74I-70I5/7/ $\underline{62}$
\end{abstract}

\section{Background}

This month in BMC Medicine, Gregory et al. [1] report on a potential new clue to understanding the etiology of autism.

The autism spectrum disorders (ASDs) are a group of neurodevelopmental conditions characterized by impairment in social, emotional and communicative skills and by ster- eotyped motor and mental processes with an onset in the first 3 years of life. ASD affects approximately $0.6 \%$ of children[2]. The number of children diagnosed with this condition has greatly increased in recent decades, likely due to increased awareness, reduced stringency of diagnostic criteria and, possibly, other factors of unknown nature [3]. 
Regarding the etiology, it is generally accepted that genetic factors play a major role and it has become clear that, with the exception of a minority of instances (about 1\%) in which the phenotype is caused by a single gene alteration, the genetic component leading to autism is complex, being based on interactions of multiple genetic changes and/or epigenetic regulation of gene expression.

Because of this complexity, decades of experimental work, even with the aid of sophisticated molecular genetic tools (such as high resolution total genome quantitative analysis, array expression analysis or high resolution single nucleotide polymorphism (SNP) array platforms) have failed to identify specific causes in any substantial proportion of cases $[4,5]$. Nonetheless, quantitative wholegenome analyses promise to identify one or a few autismspecific copy number variants (CNVs) harboring genes whose dosage alterations could be critical in causing ASD. From a number of array comparative genomic hybridization (array CGH) studies [6], even on large cohorts of patients, we have learnt that up to $10 \%$ of sporadic ASD cases do show de novo CNVs, some non-randomly associated with ASD, although none of these have been so far proven to harbor major genes causing or predisposing to ASD.

Likewise, several biological parameters, such as the postsynaptic receptor density $[7,8]$, the intercellular adhesion mechanisms $[9,10]$, the immune system [11-16], some hormonal exposures [17-22], imbalances in specific neurotransmitters $[23,24]$ and the epigenetic regulation of gene expression $[25,26]$ have emerged as possibly involved in the pathogenesis of ASD.

\section{OXTR in ASD}

This month in BMC Medicine, Gregory et al. show that there is genomic and epigenetic evidence of a reduced function of the oxytocin receptor in autism. They identified a genomic deletion containing the gene encoding for the oxytocin receptor (OXTR) in an autistic male individual and in his mother, who probably experienced obsessive-compulsive disorder (OCD). The equally affected brother did not have the same deletion but rather a hypermethylation of specific CpG islands likely to cause a reduced expression of the OXTR gene. It would be interesting to know the methylation status of the OXTR allele also in the deleted proband and in the mother, and to measure its level of expression. Likewise, one would want to know whether the maternal deletion was de novo or inherited. Could the OXTR gene be imprinted? So far there is no evidence of a possible monoallelic, parentalspecific expression in any tissue.

Regardless, the above findings prompted the analysis of the methylation status of the OXTR gene in a number of samples from autistic subjects, including brain tissue from the temporal cortex as well as peripheral blood lymphocytes. Although the sample is not a large one, the authors found a hypermethylation of specific CpG islands and a correspondingly reduced expression of the OXTR gene. This brings up the question of how did this hypermethylation occur? Was it environmentally induced or genetically determined?

The findings of Gregory $e t$ al. address two major points in the current debate on the cause and pathogenesis of autism: one related to the role of oxytocin and its receptor, the other to the possible role of epigenetic mechanisms.

Regarding the former, there is growing evidence that the oxytocin-vasopressin pathway has an influence on social behavior both under normal circumstances and in a clinical setting $[19,20,27,28]$. It has been reported that mice lacking the oxytocin gene show social deficits [29], thus strengthening the role of this nonapeptyde in modeling individual behavior. In addition, association studies in autistic cohorts have shown linkage with polymorphisms in the vasopressin and OXTR genes [21,30-32]. Duplications of the 3p25-3p26 genomic region, leading to overexpression of the OXTR gene, have been associated with a pervasive developmental disorder in a patient with obesity and behavioral issues [33], thus suggesting that increased OXTR expression can cause behavioral phenotype falling within the ASD spectrum.

\section{Epigenetic modification of OXTR}

The second issue raised by Gregory et al. deals with the epigenetic inhibition of OXTR expression in ASD. Such epigenetic modification, at least as reported so far, does not seem to be sequence based but rather of a different, as yet unknown nature. This might explain why researchers have been looking for decades for genetic mutations in ASD and yet have found almost none. An epigenetic mechanism would justify the 'unusual', non-Mendelian familial aggregations of ASD. In this respect, even the family with OXTR deficiency reported by Gregory $e t$ al. shows an unusual genotype-phenotype correlation, in that the same phenotype is caused by alterations of the same gene but due to different molecular defects (deletion versus hypermethylation).

Also, the possibility that in most ASD patients there might be an epigenomic instability is of interest in consideration of the fact that it has been shown that the epigenetic status in early fetal development can be reprogrammed by maternal behavior in a reversible way [34]. Therefore, other environmental factors, yet to be discovered, might also be able to reprogram the epigenotype of the embryo.

The epigenetic nature of ASD has been already suspected based on many instances, such as the association of ASD with conditions caused by mutations of imprinted genes 
like Angelman, Fragile X or Rett syndromes, or with quantitative alterations in regions like the 15q11-q13, also known to be imprinted [25].

\section{Conclusion}

The findings by Gregory et al. seem to open new avenues in the research on ASD, one involving the oxytocin pathway, the other the human methylome. Thus, future research in the field may take sharp turns, searching for genetic alterations responsible for ASD beyond DNA sequencing and into epigenetic regulation of gene function. Of course, before these findings can be applied as diagnostic tools or biomarkers of ASD, or can even lay down a basis for therapeutic approaches, it is necessary to confirm them in larger cohorts of patients and controls. It is true that in ASD replication studies have often failed, although this should not stop us from striving to solve this puzzle. Time and further studies will tell us whether the results seen here live up to their initial promise.

\section{Competing interests}

The authors declare that they have no competing interests.

\section{Authors' contributions}

Both authors contributed equally to the writing of this article.

\section{References}

I. Gregory SG, Connelly J, Towers A, Johnson J, Biscocho D, Markunas C, Lintas C, Abramson RK, Wright HH, Ellis P, Langford CF, Worley G, Delong GR, Murphy SK, Cuccaro ML, Persico A, Pericak-Vance MA: Genomic and epigenetic evidence for OXTR deficiency in autism. BMC Medicine 2009, 7:62.

2. Abrahams BS, Geschwind DH: Advances in autism genetics: on the threshold of a new neurobiology. Nat Rev 2008, 9:34|-355.

3. Rutter M: Autism research: lessons from the past and prospects for the future. J Autism Develop Disord 2005, 35:24I-257.

4. Freitag CM: The genetics of autistic disorders and its clinical relevance: a review of the literature. Mol Psychiatry 2007, 1 2:2-22.

5. Fombonne E: Epidemiological surveys of autism and other pervasive developmental disorders: an update. J Autism Develop Disord 2003, 33:365-382.

6. Sebat J, Lakshmi B, Malhotra D, Troge J, Lese-Martin C, Walsh T, Yamrom B, Yoon S, Krasnitz A, Kendall J, Leotta A, Pai D, Zhang R, Lee YH, Hicks J, Spence SJ, Lee AT, Puura K, Lehtimäki T, Ledbetter D, Gregersen PK, Bregman J, Sutcliffe JS, Jobanputra V, Chung W, Warburton D, King MC, Skuse D, Geschwind DH, Gilliam TC, et al.: Strong association of de novo copy number mutations with autism. Science 2007, 3 I 6:445-449.

7. Ramocki MB, Zoghbi HY: Failure of neuronal homeostasis results in common neuropsychiatric phenotypes. Nature 2008, 455:912-918.

8. Sudhof TC: Neuroligins and neurexins link synaptic function to cognitive disease. Nature 2008, 455:903-9II

9. Glessner JT, Wang K, Cai G, Korvatska O, Kim CE, Wood S, Zhang $H$, Estes A, Brune CW, Bradfield JP, Imielinski M, Frackelton EC, Reichert J, Crawford EL, Munson J, Sleiman PM, Chiavacci R, Annaiah K, Thomas K, Hou C, Glaberson W, Flory J, Otieno F, Garris M, Soorya L, Klei L, Piven J, Meyer KJ, Anagnostou E, Sakurai T, et al:: Autism genome-wide copy number variation reveals ubiquitin and neuronal genes. Nature 2009, 459:569-573.

10. Wang K, Zhang H, Ma D, Bucan M, Glessner JT, Abrahams BS, Salyakina D, Imielinski M, Bradfield JP, Sleiman PM, Kim CE, Hou C, Frackelton E, Chiavacci R, Takahashi N, Sakurai T, Rappaport E, Lajonchere CM, Munson J, Estes A, Korvatska O, Piven J, Sonnenblick
LI, Alvarez Retuerto Al, Herman El, Dong H, Hutman T, Sigman M, Ozonoff $\mathrm{S}$, $\mathrm{K}$ lin $\mathrm{A}$, et al.: Common genetic variants on 5 p I4.I associate with autism spectrum disorders. Nature 2009, 459:528-533.

II. Gerber JS, Offit PA: Vaccines and autism: a tale of shifting hypotheses. Clin Infect Dis 2009, 48:456-46I.

12. Enstrom AM, Water JA Van de, Ashwood P: Autoimmunity in autism. Curr Opin Investig Drugs 2009, 10:463-473.

13. Castellani ML, Conti CM, Kempuraj DJ, Salini V, Vecchiet J, Tete S, Ciampoli C, Conti F, Cerulli G, Caraffa A, Antinolfi P, Galzio R, Shaik Y, Theoharides TC, De Amicis D, Perrella A, Cuccurullo C, Boscolo P, Felaco M, Doyle R, Verrocchio C, Fulcheri M: Autism and immunity: revisited study. Int J Immunopathol Pharmacol 2009, 22:I5-19.

14. Blaylock RL: A possible central mechanism in autism spectrum disorders, part 3: the role of excitotoxin food additives and the synergistic effects of other environmental toxins. Altern Therapies Health Med 2009, I 5:56-60.

15. Stokstad E: Scientific community. Resignations highlight disagreement on vaccines in autism group. Science 2009, 325: I 35.

16. Horvath $\mathrm{K}$, Perman JA: Autism and gastrointestinal symptoms. Curr Gastroenterol Rep 2002, 4:25I-258.

17. Baron-Cohen S, Auyeung B, Ashwin E, Knickmeyer R: Fetal testosterone and autistic traits: a response to three fascinating commentaries. Br J Psychol 2009, I 00:39-47.

18. Auyeung B, Baron-Cohen S, Ashwin E, Knickmeyer R, Taylor K, Hackett G: Fetal testosterone and autistic traits. Br J Psychol 2009 , 100: I-22

19. Ebstein RP, Israel S, Lerer E, Uzefovsky F, Shalev I, Gritsenko I, Riebold $M$, Salomon S, Yirmiya N: Arginine vasopressin and oxytocin modulate human social behavior. Ann NY Acad Sci 2009, I | 67:87-102.

20. Heinrichs M, Domes G: Neuropeptides and social behaviour: effects of oxytocin and vasopressin in humans. Prog Brain Res 2008, I 70:337-350.

21. Israel S, Lerer E, Shalev I, Uzefovsky F, Reibold M, Bachner-Melman R, Granot R, Bornstein G, Knafo A, Yirmiya N, Ebstein RP: Molecular genetic studies of the arginine vasopressin Ia receptor (AVPRIa) and the oxytocin receptor (OXTR) in human behaviour: from autism to altruism with some notes in between. Prog Brain Res 2008, I 70:435-449.

22. Domes G, Heinrichs M, Michel A, Berger C, Herpertz SC: Oxytocin improves "mind-reading" in humans. Biol Psychiatry 2007, 6 1:731-733.

23. Anderson BM, Schnetz-Boutaud NC, Bartlett J, Wotawa AM, Wright $\mathrm{HH}$, Abramson RK, Cuccaro ML, Gilbert JR, Pericak-Vance MA, Haines JL: Examination of association of genes in the serotonin system to autism. Neurogenetics 2009, 1 0:209-2 I6.

24. Hranilovic D, Bujas-Petkovic Z, Tomicic M, Bordukalo-Niksic T, Blazevic S, Cicin-Sain L: Hyperserotonemia in autism: activity of 5HT-associated platelet proteins. J Neural Transm 2009, I | 6:493-50|.

25. Schanen NC: Epigenetics of autism spectrum disorders. Hum Mol Genet 2006, I 5:RI38-I50.

26. Jones JR, Skinner C, Friez MJ, Schwartz CE, Stevenson RE: Hypothesis: dysregulation of methylation of brain-expressed genes on the $\mathbf{X}$ chromosome and autism spectrum disorders. $\mathrm{Am} J$ Med Genet A 2008, I 46A:22 I3-2220.

27. Thompson MR, Callaghan PD, Hunt GE, Cornish JL, McGregor IS: A role for oxytocin and 5-HT(IA) receptors in the prosocial effects of 3,4 methylenedioxymethamphetamine ("ecstasy"). Neuroscience 2007, | 46:509-5 I4.

28. Neumann ID: Brain oxytocin: a key regulator of emotional and social behaviours in both females and males. J Neuroendocrinol 2008, 20:858-865.

29. Takayanagi Y, Yoshida M, Bielsky IF, Ross HE, Kawamata M, Onaka T, Yanagisawa T, Kimura T, Matzuk MM, Young LJ, Nishimori K: Pervasive social deficits, but normal parturition, in oxytocin receptor-deficient mice. Proc Natl Acad Sci USA 2005, I 02: I6096-16101.

30. Wassink TH, Piven J, Vieland VJ, Pietila J, Goedken RJ, Folstein SE, Sheffield VC: Examination of AVPR I a as autism susceptibility gene. Mol Psychiatry 2004, 9:968-972.

31. Lerer E, Levi S, Salomon S, Darvasi A, Yirmiya N, Ebstein RP: Association between the oxytocin receptor (OXTR) gene and autism: relationship to Vineland Adaptive Behavior Scales and cognition. Mol Psychiatry 2008, I3:980-988. 
32. Jacob S, Brune CW, Carter CS, Leventhal BL, Lord C, Cook EH Jr: Association of the oxytocin receptor gene (OXTR) in Caucasian children and adolescents with autism. Neurosci Lett 2007, 4I 7:6-9.

33. Bittel DC, Kibiryeva N, Dasouki M, Knoll JH, Butler MG: A 9-yearold male with a duplication of chromosome 3 p25.3p26.2: clinical report and gene expression analysis. Am J Med Genet $A$ 2006, 140:573-579.

34. Weaver IC, Cervoni N, Champagne FA, D'Alessio AC, Sharma S, Seckl JR, Dymov S, Szyf M, Meaney MJ: Epigenetic programming by maternal behavior. Nat Neurosci 2004, 7:847-854.

\section{Pre-publication history}

The pre-publication history for this paper can be accessed here:

http://www.biomedcentral.com/1741-7015/7/63/prepub

Publish with Bio Med Central and every scientist can read your work free of charge

"BioMed Central will be the most significant development for disseminating the results of biomedical research in our lifetime. "

Sir Paul Nurse, Cancer Research UK

Your research papers will be:

- available free of charge to the entire biomedical community

- peer reviewed and published immediately upon acceptance

- cited in PubMed and archived on PubMed Central

- yours - you keep the copyright

Submit your manuscript here:

http://www.biomedcentral.com/info/publishing_adv.asp 